NBER WORKING PAPER SERIES

BONUSES AND EMPLOYMENT IN JAPAN

Richard B. Freeman

Martin L. Weitzman

Working Paper No. 1878

NATIONAL BUREAU OF ECONOMIC RESEARCH

1050 Massachusetts Avenue

Cambridge, MA 02138

Apri1 1986

Research assistance from Laura Leete and $\mathrm{Kim}$ Laden was invaluable in producing this paper. The research reported here is part of the NBER's research program in Labor studies. Any opinions expressed are those of the authors and not those of the National Bureau of Economic Research. 
Japan has a relatively unique system of labor compensation. Most Japanese workers are paid large bonuses twice a year. This paper examines the cyclical movement of bonuses compared with wages and the relation of bonuses to employment in the context of the Weitzman "share economy."

The paper makes three basic points:

(1) The Japanese bonus is much more pro-cyclical than Japanese base wages, but not as cyclically variable as profits. Bonuses can be interpreted as containing a quantitatively significant revenue or profit-sharing component.

(2) Bonuses have quite different employment consequences than do base wages. Even after controlling for other economic factors, bonuses are positively related to employment, whereas base wages are negatively related to emp loyment.

(3) The bonus system of paying workers, while far from explaining the whole macroeconomic story in Japan, seems to play a role in helping to stabilize Japanese unemployment at comparatively low levels.

Richard B. Freeman $\mathrm{NBER}$

1050 Massachusetts Avenue Cambridge, MA 02138
Martin Weitzman

Department of Economics M.I.T. Room E52-353 Cambridge, MA 02139 


\section{Bonuses and Employment in Japan}

The bonus payment system, by which Japanese workers receive upwards of one quarter of their yearly pay in the form of semi-annual bonuses, is one of the exotic features of Japanese labor markets that have long fascinated outsiders. Recently interest has been heightened by the realization that the bonus system may have important macroeconomic implications along the lines of a "share economy."1 It is at least conceivable that some part of Japan's remarkable ability to stabilize unemployment at low, steady rates is due to the automatic pay flexibility that comes, with profit or revenue sharing. For a subject of such potential importance, the Japanese bonus system has been relatively little studied.

This paper reports the results of a detailed empirical analysis of Japanese labor market data designed to address certain fundamental questions about the bonus system. In it we analyse data on bonuses and other labor market variables at the one and two digit industry level from 1958 to 1983 , as well as data from a case study of an individual firm. Our interpretations have been guided by the results of interviews with Japanese employer federation representatives and labor union officials.

\section{Background}

The purpose of this section is to place the subject of the Japanese bonus system in a broader context. This is important because the bonus system is only one part of the complicated, interrelated web of institutions and attitudes that constitutes Japanese labor relations. Although we have tried hard to guard against a mono-causal interpretation of the Japanese labor market, it is quite possible that in analyzing the bonus system we inadvertently over look other important aspects of the industrial relations system which have also influenced the behavior under study. 
The following stylized facts might be taken as roughly descriptive of how the "Japanese model" of the labor market differs somewhat from others.?

(1) Firms hire workers directly out of school for "lifetime employment" (the shushin koyo system). In fact this is done primarily by the large firms, and only for their so-called "permanent" or "regular" employees(who constitute, typically, half of all workers and three-fourths of those in manufacturing). Nevertheless, the "lifetime commitment mentality" seems to be a fair characterization of the Japanese system as a whole. 3

(2) There is a steep age-earnings profile for permanent workers up to retirement age of 55 or, more recently, 60. Pay is influenced greatly by seniority. (This nenko system is beginning to erode in many places as it increasingly comes to be viewed as anachronistic. $)^{4}$

(3) The Japanese workplace is a relatively cooperative and egalitarian environment. There are few work rules, job reassignments are common, and a high degree of company loyalty motivates productivity-enhancing behavior. 5 Unions are organized along enterprise or company lines and include white collar as well as blue collar workers. In addition, blue and white collar workers in the same firm are comparatively less differentiated than elsewhere in terms of perquisites, treatment, method of payment (monthly salaries rather than hourly wages-with meaningful bonus payments), and how much they are paid.

(4) Japanese society as a whole displays a relatively intense commitment at a grass-roots level to maintaining full employment. Companies and unions seem almost ashamed to lay off workers outright. Moreover, layoffs are not generally by seniority. There appears to be a high degree of social responsibility in wage setting in Japan, as was dramatically shown by labor heeding the 1975 call for wage restraint in the face of strong inflation caused by the first oil shock. Work sharing is common, as Japanese firms tend to adjust hours 
more than employment and also to hoard more labor in downturns compared to most other developed countries. 6

(5) Bonuses are important quantitively in the average worker's pay (upwards of one-quarter of pay is in the form of a semi-annual bonus.) They are also large relative to reported company profits, ranging from from 42-76 percent of operating profits before taxes from 1965 to 1983 , and have come to constitute roughly 10 percent of net domestic product. 7

The typical Japanese worker's pay is divided into two categories. The first component is officially called kimatte shikyusuru kyuyo, "the wage that is surely paid," which we will refer to simply as base wages, --- although they are not hourly wages at all, but rather a monthly salary. (Actually the concept of "overtime" payments and work is not sharply differentiated in Japan, suggesting that employment rather than person-hours is the fundamental unit of labor usage for regular workers.) The second component is called "special cash payments" in the official statistics and the defining characteristic is held to be that it is a payment made "temporarily, unexpectedly, or erratically at the discretion of the employer." This category consists overwhelmingly of bonus payments, even though their terms and amount are often established by collective agreements and they are sometimes far from temporary, unexpected, or erratic. Bonuses are usually paid twice a year-- in summer (mostly June and July), and at year end (December). Insignificant amounts are sometimes paid in August, March, and January. Although blue-collar and low status white collar workers before the war often received a lump sum of money twice a year in addition to their regular pay, the small amount of money involved was in no way comparable to the significant semi-annual profit-sharing bonuses received by high-status white-collar employees with advanced educational backgrounds. It is only after the Second World War that the payment system emerges in its present form, as 
part of a broader trend. The main feature of this trend was a de-emphasis, to the point of near-elimination, of the invidious status categories of prewar Japan with their implicit legacies of a feudal past. As one byproduct of the immediate postwar process of democratizing the workplace, which the unions fully supported, all regular employees-- blue collar and white-- were henceforth to be paid a monthly salary instead of an hourly wage, supplemented by meaningful semi-annual bonuses for every regular employee irrespective of category. 8 The bonus payments constituted less than two months' worth of supplement after the war, rose gradually to over four months by 1973 and fell back to slightly more than three and a half months currently. 9

The bonus system is widely viewed as serving three purposes. One purpose, of particular relevance to this study, is that the bonus system provides some pay flexibility to help firms maintain the lifetime employment commitment over bad times and good. Another purpose is to compensate individual effort. Since the bonus is more discretionary than the base wage of the nenko system (which is primarily related to length of service), management typically makes some part of a particular employee's bonus depend on the merit appraisal of the individual worker's job performance.10 Finally, the bonus emphasizes, symbolically and practically, the common bond linking the company's well being with the wellbeing of its regular workers.

The timing of wage and bonus decisions generally differs. Across many unionized companies base wage determination is the primary concern of the economy-wide pattern-bargaining spring wage offensive (shunto) which usually starts in February and peaks in April.11 Negotiations over bonuses are typically done after wages are settled; and, according to management and labor representatives, are more sensitive to a company or industry's specific circumstances than base wages, which are primarily dependent on the economy's national perfor- 
mance.

Firms that consistently do well generally succeed in paying a fairly steady number of months' wages as a bonus, so that in prospering sectors and times, their bonuses are unlikely to vary much with cyclical conditions. An oft-cited example of a firm that maintains such a policy is Toyota, which has paid about the same months' worth of bonus in each year since 1968. But for every Toyota Motor Company there are companies in, say, machine tools or shipbuilding where bonuses may vary from two to ten months' pay in extreme economic conditions. At one such firm, Okuna Machine Works, the standard deviation of the percentage change of wages from 1957 to 1985 was 7, compared to a standard deviation of the percentage change of bonuses of 29. Bonuses varied from 9 months to 2 months of pay in post-war years. The majority of firms hold a position in between Toyota and okuna. For all manufacturing firms aggregated together, the standard deviation of the $\log$ change in bonuses from 1959 to 1983 was .072 compared to a standard deviation of the log change of wages of .055 .12

Surveys conducted by Nikkeiren, the employers' federation, show that most firms think of bonuses as being influenced by profitability. Among corporations that make an explicit agreement with employees about bonus payments, some $15 \%$ of such contracts contain profit-sharing clauses. 13

The Key Issues

There are three critical issues in evaluating the macroeconomic implications of the Japanese bonus system.

First is the extent to which bonuses are more "flexible" with respect to profits or revenues than are wages, and thus operate as a form of profit or revenue sharing.

Second is the effect of bonuses on employment. If bonuses are a cost to employers similar to wages, with no share component, bonuses plus wages are the 
relevant variable defining labor demand, with increases in bonuses reducing employment just as increases in wages do; contrarily, if bonuses have a nonnegligible profit-sharing component, they might have a very different relation to employment.

The third, and perhaps most difficult issue to assess is the contribution of a bonus system that operates along share economy lines to the overall performance of the Japanese labor market.

The remainder of the paper examines these three issues. Sections II and III analyse the determinants of bonuses and the link between bonuses and employment using data for the entire Japanese economy, for manufacturing, and for more disaggregated two digit industries, largely within manufacturing. Section IV turns to the macro-economic implications of our findings.

\section{Economic Fluctuations and Bonuses}

Are bonuses more responsive to economic conditions than are wages, or are bonuses simply a markup of wages?

One direct way to examine the relative flexibility of bonuses and wages to economic conditions is to regress the ratio of monthly bonuses to monthly wages (the number of months of salary paid in bonuses, which is how most Japanese think of them) on measures of aggregate or industry economic conditions, conditional on past values of wages and bonuses.

Table 1 contains the results of such an analysis for all industry and for manufacturing in Japan. The dependent variable is the log of the ratio of bonuses to wages from the series of the Japanese Ministry of Labor. To measure economic conditions we have used: the $\log$ of profits (TT) as reported in the Statistical Survey of Corporate Enterprise series of corporate operating profits for firms of all sizes; and two related measures of revenues: net domestic product (NDP) taken from the Japanese Economic Planning Agency data on net out- 
put by industrial origin at market prices; and corporate value added (VA) as reported in the Statistical Survey of Corporate Enterprises. All of the nominal variables are deflated by the wholesale price index series of the Bank of Japan, with the manufacturing price series used for manufacturing, and all three indicators of economic conditions are measured over the Japanese fiscal year (Apri) 1-March 31), which correlates them more closely with the largely spring time determination of upcoming wage and bonus levels than calendar year data. In addition to the measures of economic conditions, the equations include a linear and quadratic function of time, and lagged values of bonuses $\left(B_{-} 1\right)$ and wages $\left(W_{-1}\right)$ introduced separately to allow for differential autoregressiveness of the series.

The calculations provide a clear answer to the question of the relative responsiveness of wages and bonuses to economic conditions: in every case, the coefficient on the measure of economic conditions is positive and significant, indicating that bonuses are more responsive to economic conditions than are wages. Moreover, the coefficient on lagged bonuses is positive and that on lagged wages is negative, of roughly comparable magnitude, indicating that a "partial adjustment" type model of the bonus to wage ratio with persistence of bonuses and wages over time is consistent with the data.

To see whether the results hold up at a more disaggregated level of analysis, we have estimated equations for the ratios of bonuses to wages for 2 digit industries over the same time period. The results of this analysis are given in table 2 in terms of the number of industries in which bonuses are more (less) responsive to the relevant explanatory variable than are wages, categorized by the size of the $t$ statistic. As can be seen, the analysis supports the finding that bonuses are more responsive than wages to revenues and profits at the twodigit level of aggregation, with the vast majority of industries obtaining posi- 
Table 1: Estimates of the Effect of Economic Conditions on the Log Ratio of Bonuses to Wages, 1959-1983*

Constant Iime (time) $)^{2} \ln (T T) \underline{\ln (V A)} \ln (N D P) \quad \ln \left(B_{-1}\right) \quad \ln \left(W_{-1}\right) \quad R^{2}$ SEE All Industry

\begin{tabular}{|c|c|c|c|c|c|c|c|c|c|}
\hline 1. & -.08 & $\begin{array}{l}-.09 \\
(.03)\end{array}$ & $\begin{array}{l}.001 \\
(.0002)\end{array}$ & $\begin{array}{l}.18 \\
(.02)\end{array}$ & & $\begin{array}{l}.67 \\
(.08)\end{array}$ & $\begin{array}{l}-.63 \\
(.11)\end{array}$ & .98 & .018 \\
\hline 2 . & -.29 & $\begin{array}{l}-.14 \\
(.04)\end{array}$ & $\begin{array}{l}.001 \\
(.0003)\end{array}$ & $\begin{array}{l}.38 \\
(.05)\end{array}$ & & $\begin{array}{l}.49 \\
(.09)\end{array}$ & $\begin{array}{l}-.58 \\
(.12)\end{array}$ & .98 & .019 \\
\hline 3. & 1.53 & $\begin{array}{l}-.17 \\
(.09)\end{array}$ & $\begin{array}{l}.001 \\
(.001)\end{array}$ & & $\begin{array}{l}.42 \\
(.17)\end{array}$ & $\begin{array}{l}.47 \\
(.15)\end{array}$ & $\begin{array}{l}-.45 \\
(.20)\end{array}$ & .94 & .032 \\
\hline \multicolumn{10}{|c|}{ Manufacturing } \\
\hline 4. & .62 & $\begin{array}{l}-.12 \\
(.04)\end{array}$ & $\begin{array}{l}.001 \\
(.0002)\end{array}$ & $\begin{array}{l}.20 \\
(.02)\end{array}$ & & $\begin{array}{l}.71 \\
(.07)\end{array}$ & $\begin{array}{l}-.64 \\
(.28)\end{array}$ & .98 & .021 \\
\hline 5. & .94 & $\begin{array}{l}-.21 \\
(.03)\end{array}$ & $\begin{array}{l}.001 \\
(.0002)\end{array}$ & $\begin{array}{l}.49 \\
(.04)\end{array}$ & & $\begin{array}{l}.53 \\
(.06)\end{array}$ & $\begin{array}{l}-.68 \\
(.10)\end{array}$ & .99 & .018 \\
\hline 6. & 2.55 & $\begin{array}{l}-.22 \\
(.10)\end{array}$ & $\begin{array}{l}.001 \\
(.001)\end{array}$ & & $\begin{array}{l}.38 \\
(.14)\end{array}$ & $\begin{array}{l}.41 \\
(.16)\end{array}$ & $\begin{array}{l}-.25 \\
(.23)\end{array}$ & .94 & .042 \\
\hline
\end{tabular}

Source: See Data Appendix

*Equations including TT and VA are restricted to 1960-1983. 
Table 2: Summary of the Coefficients of the Effect of Profits and Revenues on $\log$ Bonuses/Wages

\section{(a) Responses to Profits}

Number of industries

Bonuses more responsive

$|t|<1 \quad$ yes $\quad 1$

$1<t \mid<2 \quad 1 \quad 0$

$2<t \mid<3 \quad 0 \quad 0$

$|t|>3 \quad 10 \quad 0$

Total no

0

0

0

1 (b) Responses to Value Added

Number of industries
bonuses more responsive yes

0

1

4

8

13 no

1

0

0

0

1 (c) Responses to NDP Number of industries bonuses more responsive

$\begin{array}{ll}\text { yes } & \text { no } \\ 5 & 2\end{array}$

$4 \quad 0$

6

0

0

0

15
0

2

Source: Panels A\& B industries included: $M I, C N, W R, R E, F O, T X, C H, C E, I S$, $N F, F B, M A, E Q, T Q$. See Data Appendix for industry code definitions.

Panel $C$ industries included: $M I, C N$, WR, RE, TC, EL, FO, TX, CH, PA, $F B, M A, E Q, T Q, F I, P E, P C$. See Data Appendix for industry code definitions.

Based on regressions of $\log$ (Bonus/Wages) on time, $\log$ (Bonuses $(-1)$ ), $\log$ (Wages $(-1)$ ) and the log of the relevant measure of economic activity. 
tive and often significant $(t>2)$ impact coefficients. We conclude that although bonuses are not a simple proportion of profits or revenues they depend substantially on those variables, to a much greater extent than wages, and thus vary more with economic conditions than do wages.

How do bonuses and wages, taken as separate variables, respond to economic conditions? Do both wages and bonuses both respond positively to conditions with the table 1 results due to the greater responsiveness of bonuses, or are bonuses responsive and wages inflexible?

To answer these questions we have estimated the following equations:

$$
\begin{aligned}
& \text { (1a) } \log B=A+\lambda a \log T T(\text { or } R)+(1-\lambda) \log B_{-I}+c T \\
& \text { (1b) } \left.\log W=A^{\prime}+b \lambda^{\prime} \log T T \text { (or } R\right)+\left(I-\lambda^{\prime}\right) \log W-I+C^{\prime} T
\end{aligned}
$$

While the results of our analysis, given in table 3 , show that bonuses are invariably more responsive to conditions than are wages, the estimated coefficients tell a somewhat different story for the effect of revenues than of profits on the two measures of pay. While both bonuses and wages are positively related to revenues, only bonuses are significantly affected by profits. Since our measure of profits is an "after-bonus" measure the finding of a positive profit-bonus relation is particularly striking. 14 Finally, note that interpreting the coefficient on the lagged dependent variable as a partial adjustment parameter, the implied adjustment parameter $\lambda$ is invariably larger in the bonus than wage equation, strengthening the conclusion that bonuses are more responsive than wages.

\section{Alternative Specifications}

Thus far, we have estimated models in which bonuses and wages are endogenous variables. Given the timing of negotiations noted in section 1 , it is also reasonable to examine a model in which wages are exogenous (given, say, by the 
Shunto offensive) and bonuses dependent on wages and economic conditions. If bonuses are simply a markup of wages, as has sometimes been alleged, then the profit or revenue variables would not have a significant effect in this regression. Contrarily, if bonuses were determined solely by "sharing," the wage term would not enter significantly. 15

To examine this possibility we estimate the following equation for all industry and manufacturing:

(2) $\log B=A+\lambda a \log T T($ or $R)+(1-\lambda) \log B_{-1}+\lambda c \log W+d T$

The results given in 1 ines 1 and 2 and 5 and 6 of table 4 show that while contemporaneous wages are closely related to bonuses, profits or revenues also have highly significant effects, indicating that bonuses depend on both factors. They are neither a pure markup of wages nor a pure markup of profits. Finaliy, in the simple share economy model workers are presumed to be paid a fixed proportion of profits per worker. To see whether our data are consistent with this view we estimate an equation in which we replace profits and revenues by profits per worker and revenues per worker. We record these results in 1 ines 3 and 4 and 7 and 8 of table 4 . In this calculation we have simply divided fiscal year profits (revenues) by fiscal year employment; we have also experimented with calculations using last period's employment (see table 6). As employment is relatively stable and profits highly variable it does not matter substantially how we model the profit/employment or revenue/employment variable. As can be seen in table 4, the resultant estimates are consistent with our interpretation of bonus determination as paying a share of profits per worker.

Comparing our results to those of other scholars, we are in accord with Koshiro and Weitzman, (who use somewhat different data) in finding bonuses to depend significantly on profits; in addition, however, we find bonuses are related to another measure of economic performance, revenues. With respect to the responsiveness of wages to profitability, we cannot find any formal sta- 
Table 3: Coefficients and Standard Errors for Effects of Net Domestic Product, Value Added, and Profits, on Bonuses and Wages, 1959-1983*

\section{A. All Industry}

Dependent variable constant IIME In(NDP) InTT InVA InB-I InW-I SEE

1. In bonuses $\quad-.33 \quad-.013 \quad .44$

2. In wages

$$
1.41
$$$$
(.002) \quad(.34)
$$

3. In bonuses

$$
\begin{array}{ll}
-.13 \quad & -.009 \\
& (.006)
\end{array}
$$

$$
\begin{aligned}
& .09 \\
& (.05)
\end{aligned}
$$

.94

(.09)

4. In wages

.21

$-.01$

$-.05$

$(.01)$

$(.07)$

$1.12 \quad .058$

$(.18)$

$.53 \quad .051$

$(.22)$

5. In bonuses

$$
\begin{array}{ll}
-1.36 \quad-.012 \\
& (.005)
\end{array}
$$

$$
\begin{array}{ll}
.28 & .74 \\
(.10) & (.12)
\end{array}
$$

\begin{tabular}{|c|c|c|c|c|c|c|c|c|}
\hline 7. In bonuses & .17 & $\begin{array}{l}-.004 \\
(.006)\end{array}$ & $\begin{array}{l}.38 \\
(.11)\end{array}$ & & & $\begin{array}{l}.63 \\
(.13)\end{array}$ & & .045 \\
\hline $8.1 n$ wages & 1.24 & $\begin{array}{l}.002 \\
(.009)\end{array}$ & $\begin{array}{l}.21 \\
(.09)\end{array}$ & & & & $\begin{array}{l}.70 \\
(.18)\end{array}$ & .045 \\
\hline 9. in bonuses & -0.59 & $\begin{array}{l}-.004 \\
(.006)\end{array}$ & & $\begin{array}{l}.14 \\
(.04)\end{array}$ & & $\begin{array}{l}.87 \\
(.07)\end{array}$ & & .045 \\
\hline $10.7 n$ wages & .22 & $\begin{array}{c}-.012 \\
(.01)\end{array}$ & & $\begin{array}{l}-.05 \\
(.05)\end{array}$ & & & $\begin{array}{l}1.14 \\
(.14)\end{array}$ & .049 \\
\hline $11.7 \mathrm{n}$ bonuses & -2.30 & $\begin{array}{l}-.004 \\
(.005)\end{array}$ & & & $\begin{array}{l}.37 \\
(.08)\end{array}$ & $\begin{array}{l}.63 \\
(.09)\end{array}$ & & .038 \\
\hline 12. in wages & .15 & $\begin{array}{r}-.004 \\
(.01)\end{array}$ & & & $\begin{array}{l}.05 \\
(.11)\end{array}$ & & $\begin{array}{l}.94 \\
(.22)\end{array}$ & .050 \\
\hline
\end{tabular}

.043

6. In wages

$$
\begin{array}{ll}
.25 \quad-.002 \\
(.01)
\end{array}
$$

$.81 \quad .057$

B. Manufacturing

Source: Calculated by least squares using data described in Appendix. The adjusted $\mathrm{R}^{2}$ for every equation was .99

* Equations including TT and VA cover 1960-1983. 
tistical evidence that base wages alone respond to profits, though we do find that wages respond to revenues. Some of the Phillips-curve-like pay-formation regressions in the literature have picked up, we note, a dependence of pay upon profits.16 But in these exercises the authors typically attempt to explain the formation of total pay--defined as wages plus bonuses and profits may be primarily affecting the bonus component. On the basis of our findings the entire subject of empirical Phillips curve measurements for Japan is worthy of reexamination, with more careful attention focused on separating out base wages from bonuses in the pay-formation process.

Leaving aside the controversial issue of whether or not base wages themselves are more responsive to conditions than in other countries, we conclude that in Japan bonuses respond more than base wages to economic conditions.

\section{How Do Bonuses Affect Employment?}

The finding that bonuses contain at least some "share" component raises the possibility that they have a different impact on employment than wages. In this section we estimate several demand for labor type models designed to examine the possibility. We start with a simple null hypothesis: that bonuses are simply part of normal labor costs comparable to wages, so that the appropriate measure of cost is $(W+B)$, with the division of compensation between wages and bonuses having no effect on outcomes. In particular we estimate two comparable partial adjustment forms of a demand relation between employment ( $E$ ), bonuses $(B)$, wages $(W)$, and measures of the level of demand $(X)$ :

(3a) $\ln E=A+b \ln (W+B)+\lambda c \ln B+\lambda d X+(1-\lambda) \ln E_{-1}+$ eTime

(3b) $\ln E=A^{\prime}+\lambda^{\prime} b^{\prime} \ln W+\lambda^{\prime} c^{\prime} \ln (W+B)+\lambda^{\prime} d^{\prime} x+\left(1-\lambda^{\prime}\right) \ln E_{-1}+e^{\prime} T$ ime

In equation (3a), the hypothesis that bonuses are just part of normal labor cost is tested by the coefficient on $\ln (B)$ : if the form of compensation is 
Table 4: Coefficients and Standard Errors for Alternative Specifications of the Effect of Economic Conditions on Log Bonuses, 1960-1983.

Constant Iime $\underline{\ln (T T)} \underline{\ln (V A)} \ln (W) \ln T T / E$ InVA/E $\ln \left(B_{-1}\right)$ SEE

\section{All Industries}

\begin{tabular}{|c|c|c|c|c|c|c|c|c|}
\hline 1. & -3.34 & $\begin{array}{l}-.02 \\
(.004)\end{array}$ & $\begin{array}{l}.11 \\
(.03)\end{array}$ & & $\begin{array}{l}.75 \\
(.11)\end{array}$ & & $\begin{array}{l}.43 \\
(.09)\end{array}$ & .026 \\
\hline 2. & -3.89 & $\begin{array}{l}-.02 \\
(.003)\end{array}$ & & $\begin{array}{l}.26 \\
(.06)\end{array}$ & $\begin{array}{l}.66 \\
(.10)\end{array}$ & & $\begin{array}{l}.33 \\
(.09)\end{array}$ & .024 \\
\hline 3. & .89 & $\begin{array}{l}-.01 \\
(.01)\end{array}$ & & & & & $\begin{array}{l}.99 \\
(.08)\end{array}$ & \\
\hline 4. & 2.03 & $\begin{array}{l}-.01 \\
(.006)\end{array}$ & & & & $\begin{array}{l}.25 \\
(.13)\end{array}$ & $\begin{array}{l}.87 \\
(.11)\end{array}$ & \\
\hline & \multicolumn{8}{|c|}{ B. Manufacturing } \\
\hline 5. & -3.07 & $\begin{array}{l}-.01 \\
(.005)\end{array}$ & $\begin{array}{l}.14 \\
(.03)\end{array}$ & & $\begin{array}{l}.61 \\
(.13)\end{array}$ & & $\begin{array}{l}.52 \\
(.09)\end{array}$ & \\
\hline 6. & -3.87 & $\begin{array}{l}-.01 \\
(.005)\end{array}$ & & $\begin{array}{l}.32 \\
(.06)\end{array}$ & $\begin{array}{l}.48 \\
(.12)\end{array}$ & & $\begin{array}{l}.40 \\
(.09)\end{array}$ & \\
\hline 7. & 1.41 & $\begin{array}{l}-.01 \\
(.01)\end{array}$ & & & & & $\begin{array}{l}.93 \\
(.06)\end{array}$ & \\
\hline 8. & 2.96 & $\begin{array}{l}-.01 \\
(.006)\end{array}$ & & & & $\begin{array}{l}.37 \\
(.09)\end{array}$ & $\begin{array}{c}.77 \\
(.08)\end{array}$ & \\
\hline
\end{tabular}

Source: See Data Appendix.

The $R^{2}$ for every equation was .99 .

${ }^{*}$ Equations including $E$ are restricted to 1960-1982. 
irrelevant to employment and the data are determined by demand forces, the coefficient on in (B) will be (approximately) 0 while that on $\ln (W+B)$ will be negative. In equation (3b), the test of the hypothesis that the composition of compensation is irrelevant to employment is that the coefficient on $\ln (W+B)$ be negative and that on in $W$ be zero. By including both bonus and wage variables as separate factors in the equation our model differs from those of other analysts of demand for labor in Japan.17

As the reader will note, it is the log form of the demand equations which dictates estimation of the two comparable forms. If we modelled demand as a linear equation, one of the two equations would be redundant.

A significant problem with demand relations of this form relates to the measurement of "level of demand" factors. Somé analysts enter output measures or output measures instrumented on other variables to measure the level of demand. Other analysts prefer to exclude such variables due to the production function relation between output and employment. Such exclusions yield reasonable demand relations for some European countries but not for the U.S. (see Symons and Layard). To make sure our results do not depend on how we treat demand shift-variables, we include output measures in some regressions and exclude them from others, with, as will be seen, little effect on our findings. Another problem with models of this form relates to specifying the causality as going from wages (bonuses) to employment in an aggregate economy with extremely low unemployment. Most analyses of labor demand, in fact, focus on manufacturing where one can plausibly argue that wages are set economy-wide, making employment a function of wages at the sector level. A priori, one anticipates that a demand model will fit a single sector better than it will fit an entire essentially full-time employment labor market.

Table 5 presents our estimates of the impact of wages, wages plus bonuses, and of bonuses, on employment. Panel A treats the manufacturing industries where 
our results are particularly striking; Panel B treats the entire economy. The even-numbered equations exclude output; the odd-numbered equations include output as a measure of the level of demand. In addition to the calculations in the table, we experimented with various other demand-shift variables (including profits) and with instrumental variable estimates of demand shifts, instrumenting output on such factors as exports, money supply, etc. Because inclusion of the output variables has only a modest impact on our estimated bonus and wage coefficients, the way in which we treat demand shift variables is not a critical issue in the analysis, (in contrast to the importance of output terms in U.S. labor demand equations).

The key finding, which runs through all the calculations, is that bonuses have a markedly different effect on employment than do wages, obtaining positive rather than negative coefficients in the estimates. When our two variables are bonuses and bonuses plus wages the, coefficient on bonuses is significantly positive while the coefficient on wages plus bonuses is significantly negative. When bonuses plus wages are included with wages, the wage term obtains a negative coefficient while the bonuses plus wage yields a positive coefficient.

The strength of our finding differs, we note, between highly cyclical manufacturing and the rest of industry. In manufacturing, the two elements of compensation have such different effects that we can fairly readily reject our null hypothesis. In all industry, the weaker estimated negative effect of wages (wages plus bonuses) on employment gives a more equivocal result, although even here it is apparent that bonuses have a positive impact on employment different from the effect of wages. 18

\section{Probing the Results}

The finding that bonuses are positively rather than negatively associated with employment, (in contrast to wages) is sufficiently striking as to merit 
Table 5: Coefficients and Standard Errors for Estimates of Bonuses and Wages on Log Employment, 1959-82

\section{Panel A: Manufacturing}

\begin{tabular}{|c|c|c|c|c|c|c|c|c|}
\hline $\begin{array}{l}\text { Con- } \\
\text { stant }\end{array}$ & Time & $\begin{array}{l}\ln \\
(W+B)\end{array}$ & $\ln (w)$ & $\ln (B)$ & $\begin{array}{l}\text { In } \\
\text { NDP }\end{array}$ & $\begin{array}{l}\ln \\
\left(E_{-1}\right) \\
\end{array}$ & $R^{2}$ & SEE \\
\hline 7.21 & $\begin{array}{l}.0002 \\
(.002)\end{array}$ & $\begin{array}{l}-.37 \\
(.06)\end{array}$ & & $\begin{array}{l}.21 \\
(.05)\end{array}$ & $\begin{array}{l}.15 \\
(.03)\end{array}$ & $\begin{array}{l}.59 \\
(.05)\end{array}$ & .99 & .009 \\
\hline 10.37 & $\begin{array}{l}.0001 \\
(.003)\end{array}$ & $\begin{array}{l}-.33 \\
(.10)\end{array}$ & & $\begin{array}{l}.28 \\
(.07)\end{array}$ & & $\begin{array}{l}.72 \\
(.08)\end{array}$ & .98 & .014 \\
\hline 6.60 & $\begin{array}{r}.0001 \\
(.002)\end{array}$ & $\begin{array}{c}.49 \\
(.15)\end{array}$ & $\begin{array}{l}-.65 \\
(.14)\end{array}$ & & $\begin{array}{l}.16 \\
(.03)\end{array}$ & $\begin{array}{l}.59 \\
(.05)\end{array}$ & .99 & .009 \\
\hline 4.39 & $\begin{array}{l}.0008 \\
(.003)\end{array}$ & $\begin{array}{c}.83 \\
(.23)\end{array}$ & $\begin{array}{l}-.87 \\
(.25)\end{array}$ & & & $\begin{array}{l}.74 \\
(.08)\end{array}$ & .98 & .015 \\
\hline
\end{tabular}

Panel B: All Industry

\begin{tabular}{|c|c|c|c|c|c|c|c|c|c|}
\hline 5. & 6.59 & $\begin{array}{l}.005 \\
(.003)\end{array}$ & $\begin{array}{l}-.39 \\
(.16)\end{array}$ & & $\begin{array}{l}.14 \\
(.13)\end{array}$ & $\begin{array}{l}.32 \\
(.09)\end{array}$ & $\begin{array}{l}.56 \\
(.14)\end{array}$ & .99 & .019 \\
\hline 6. & 2.80 & $\begin{array}{l}.003 \\
(.004)\end{array}$ & $\begin{array}{l}-.20 \\
(.20)\end{array}$ & & $\begin{array}{l}.18 \\
(.16)\end{array}$ & & $\begin{array}{l}.86 \\
(.14)\end{array}$ & .99 & .025 \\
\hline 7. & 6.20 & $\begin{array}{l}.005 \\
(.003)\end{array}$ & $\begin{array}{l}.14 \\
(.38)\end{array}$ & $\begin{array}{l}-.40 \\
(.39)\end{array}$ & & $\begin{array}{l}.33 \\
(.09)\end{array}$ & $\begin{array}{l}.56 \\
(.14)\end{array}$ & .99 & .01 \\
\hline 8. & 1.99 & $\begin{array}{l}.002 \\
(.004)\end{array}$ & $\begin{array}{l}.39 \\
(.50)\end{array}$ & $\begin{array}{l}-.41 \\
(.51)\end{array}$ & & & $\begin{array}{l}.88 \\
(.14)\end{array}$ & .99 & .025 \\
\hline
\end{tabular}

Source: see Data Appendix. 
additional probing.

Could the result be due to some type of aggregation bias?

To see if the result holds up at a more disaggregated level we estimated equations like those in table 5 for separate two digit industries and found results consistent with those in the table. In these calculations bonuses obtain positive coefficients in 6 of 10 manufacturing industries in ( $3 a$ ) and bonuses plus wages obtain positive coefficients in the same 6 in equation (3b), with 5 of the positive coefficients having $t>1.19$ In 6 nonmanufacturing industries, by contrast, the results were weaker, which is consistent with the weak economy-wide results obtained in panel B of the table. 20 our strongest finding is clearly for manufacturing.

Could the result be due to some form of reverse causality or related problem in which bonuses and employment are positively correlated because increases in employment (reflecting good times) cause higher bonuses?

To examine this possibility we have estimated two lagged models which enable us to "test" whether employment determines bonuses or bonuses determine employment by examining the lagged impact of bonuses on employment and of employment on bonuses in the spirit of Sims-Granger causality tests. For simplicity, we report results where all variables are defined on a calendar year basis; the results with bonuses related to fiscal year variables as in our earlier tables gives comparable results to those in the table. The results, given in table 6 , suggest that the causal link is from bonuses to employment rather than from employment to bonuses. In manufacturing, lagged bonuses have a positive effect on employment (in contrast to the negative effect of lagged wages on employment), while lagged employment has a negative effect on bonuses. In all industry, bonuses have an insignificant positive impact on employment (contrasted to a negative effect for wages) whereas employment negatively 
effects bonuses. These results are inconsistent with an employment causes bonuses model but are, we note, consistent with a share model interpretation of the data, as increases in employment reduce workers' earnings from profit sharing in the share mode 1.

Taking our finding of a positive bonus-employment relation at face value, how might we go about interpreting it?

There seem to be two basic modes of interpretation: one in which bonuses are viewed as operating along theoretic share economy lines; and one in which bonuses are taken as an indicator of the level of demand in a given period.

First, from a share economy perspective, one may want to read the result as indicating that bonuses, while part of the attractiveness of jobs to workers, are not fully part of the marginal cost of employment to firms. From this perspective the data suggest that we are estimating a mixed supply and demand reduced form equation, with $W+B$ primarily reflecting supply influences on employment and $W$ primarily reflecting demand influences, with the gap between them indicating the "excess demand" for labor in a share system. 21

What might one do to test such an interpretation? A purist would develop a detailed econometric model of supply and demand disequilibrium to estimate the "structural equations" and to evaluate the predicted excess demand for labor. To implement such a program in practice would require more data on the Japanese labor market than the wage, employment, and bonus series that we have analysed here. For example, one would want some direct measure of the share parameter that in principle determines the contract, rather than measures of bonuses. (Bonuses differ significantly from share parameters in that they change for two reasons: changes in labor's share of profits (revenues) or changes in the level of profits (revenues).) One would also want direct measures of vacancies by sector and over time to indicate potential changes and differences in "excess 
demand for labor" as bonuses vary. It would also be useful to have evidence on patterns of recruitment of new workers. In the absence of such data, and the need to make specific and somewhat arbitrary assumptions about disequilibrium forms, we are loathe to pursue this line with our data. Virtually any reasonable disequilibrium formulation will end up with reduced form mixed supply and demand equations like those we have estimated, with predicted coefficients having signs like those we have found.

A second possible interpretation of our finding is that bonuses are a "proxy" for shifts in labor demand. We do not think that this offers as good an interpretation of the data. First, we have attempted to control for such demand shifts by the explicit inclusion of output terms, yet the signs on bonuses and wages were unchanged. Additionally, the causal lag relation between employment and bonuses we've found is inconsistent with this view. Furthermore, it is not enough for a particular firm or sector to "demand" more labor in a full employment economy; a plausible story must be told about how the labor is obtained--- e.g., through increased pay $(W+B)$ on the supply side. Of course it is still logically possible to argue that bonuses are a superior measure of the level of the labor demand schedule. (After a11, we did find them to vary substantially with the cycle.) Even this interpretation, however, clearly supports the notion that bonuses are not part of normal labor cost.

In any case, whatever the ultimate explanation, bonuses are different from wages in Japan, in their effects on employment as well as in their sensitivity to economic conditions. Without pushing the "share economy" interpretation of the data too far, our results do seem to have the "flavor" of such a system. IV. Macroeconomic Implications of the Bonus System

We come now to the difficult question of whether the Japanese bonus system influences macroeconomic performance, and more particularly, whether it helps 
Table 6: Alternative Models of Lagged Relations: 1959-1983*

\section{Manufacturing}

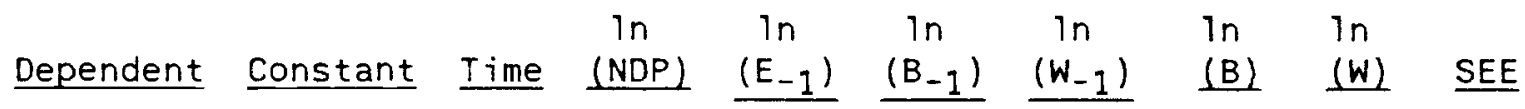
Model I: Wages, Bonuses and Employment taken as endogenous.

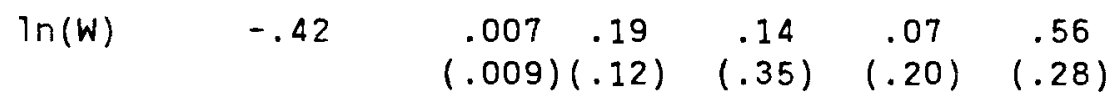

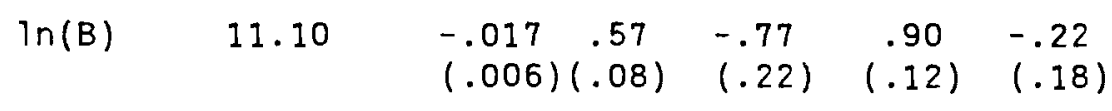

$\ln (E)$

$$
\begin{array}{llllll}
9.13 & -.003 & .19 & .42 & .12 & -.24 \\
& (.003)(.04) & (.11) & (.06) & (.08)
\end{array}
$$

Model II: Bonuses and Employment endogenous; Wages exogenous.

$\begin{array}{llllllll}\ln (B) & 7.10 & -.02 & .47 & -.57 & .72 & .14 & .027 \\ & & (.006)(.08) & (.19) & (.09) & (.14) & \\ \ln (E) & 7.67 & -.002 & .21 & .53 & .08 & -.26 & .010 \\ & & (.002)(.03) & (.07) & (.03) & (.05) & \end{array}$

\section{All Industry}

\begin{tabular}{|c|c|c|c|c|c|c|}
\hline $\ln (W)$ & 8.09 & $\begin{array}{l}.009 \\
(.008)\end{array}$ & $\begin{array}{l}.51 \\
.14)\end{array}$ & $\begin{array}{l}-.46 \\
(.32)\end{array}$ & $\begin{array}{l}.29 \\
(.19)\end{array}$ & $\begin{array}{l}.14 \\
(.26)\end{array}$ \\
\hline $\ln (B)$ & 5.72 & $\begin{array}{l}-.01 \\
(.005)\end{array}$ & $\begin{array}{l}.60 \\
.10)\end{array}$ & $\begin{array}{l}-.48 \\
(.23)\end{array}$ & $\begin{array}{c}.81 \\
(.14)\end{array}$ & $\begin{array}{c}-.18 \\
(.18)\end{array}$ \\
\hline $\ln (E)$ & 6.43 & $\begin{array}{l}.006 \\
(.004)\end{array}$ & $\begin{array}{l}.23 \\
.08)\end{array}$ & $\begin{array}{l}.55 \\
(.17)\end{array}$ & $\begin{array}{l}.08 \\
(.10)\end{array}$ & $\begin{array}{r}-.25 \\
(.13)\end{array}$ \\
\hline
\end{tabular}

Model I: Wages, Bonuses and Employment taken as endogenous.

\begin{tabular}{|c|c|c|c|c|c|}
\hline $\ln (B)$ & 1.07 & $\begin{array}{l}-.016 \quad .41 \\
(.004)(.13)\end{array}$ & $\begin{array}{l}-.22 \\
(.21)\end{array}$ & $\begin{array}{l}.59 \\
(.10)\end{array}$ & $\begin{array}{l}.29 \\
(.16)\end{array}$ \\
\hline $\ln (E)$ & 6.87 & $\begin{array}{l}.004 \quad .35 \\
(.003)(.09)\end{array}$ & $\begin{array}{l}.52 \\
(.15)\end{array}$ & $\begin{array}{l}.05 \\
(.07)\end{array}$ & $\begin{array}{l}-.32 \\
(.11)\end{array}$ \\
\hline
\end{tabular}

Mode I II: Bonuses and Employment endogenous; Wages exogenous.

Source: See Data Appendix.

The $R^{2}$ for every equation was .99

* Equations including $E$ are restricted to 1959-1982. 
account for the low unemployment rates found in Japan over the last quarter century. 22 other things being equal, it stands to reason that the existence of a bonus component of pay with a more automatic pro-cyclical link than base wages should help an economy to maintain a higher level of employment than if wages alone were paid. But how important a factor, quantitatively, is this likely to be in the Japanese case? Given the current state of macroeconomics, with widely divergent schools of thought, it is not clear how to pose the appropriate hypothesis formally so that the existing data might, at least in principle, allow us to extricate a reasonably controversy-free answer. Rather than trying to confront the issue head on with a formal model, we limit ourselves here to some rough calculations designed to give likely orders of magnitudes of effects.

The bonus itself is about one fourth of an average worker's total pay. By running regressions in logarithms we have estimated the elasticity of aggregate bonus response to changed aggregate profits at about. 09 (see line 3, table 3 ). Converting this parameter to a linear equivalent, the same elasticity of .09 is obtained if 99 of the bonus payment is strictly proportional to profits, while the other $91 \%$ is like a fixed constant. The folowing crude imputation can then be made. About $2.25 \%(9 \% \times 25 \%)$ of a Japanese worker's total pay can be treated as genuine profit sharing income, compared with the other $97.75 \%$, which for economic purposes is better described as being like an imputed base wage.

A rough check on this calculation is possible using our equations linking bonuses to revenues. The elasticity of aggregate bonus payments with respect to aggregate value added, or revenue, was estimated to be about. 44 (see 1 ine 1 ) table 3$)$. Converting to an equivalent-elasticity linear revenue-sharing formula makes $44 \%$ of the bonus payment strictly proportional to revenues, while the other $56 \%$ is like a fixed constant. If aggregate imputed base wages are roughly three fourths of aggregate revenues, that leaves one fourth for gross profits. By this calculation, $11 \%(1 / 4 \times 44 \%)$ of the bonus payment is strictly proportional to 
profits, while the rest is like a fixed constant. Following this line of reasoning, about $2.75 \%(11 \% \times 25 \%)$ of a typical Japanese worker's total pay can be treated as genuinely proportional to profits, while the remainder is like an imputed base wage.

Splitting the difference between the high (2.75\%) and low (2.25\%) calculations, we can make the following very rough statement: in any year about $97.5 \%$ of an average Japanese worker's total pay is like a fixed imputed base wage, while 2.58 automatically responds directly to profits. If pay contracts are annually renegotiated, the marginal cost to the employer of hiring an extra unit of labor in any given year is just the (imputed) base wage, as opposed to total pay. 23 The relevant theory then predicts that the Japanese economy should behave like an otherwise absolutely identical (but hypothetical) wage economy whose wages are $2.5 \%$ lower than actual Japanese pay (base wages plus bonus) but whose maintained levels of aggregate demand (autonomous spending, the money supply, and world demand for Japanese exports) are the same.24 In other words, if someone who thought that Japan was a wage economy and has just now been informed that it is in fact (partially) a revenue or profit-sharing economy wants to know what difference that makes, the answer is: the same difference as if money wages were perpetually $2.5 \%$ lower than what they appeared to be.

While the exact ramifications of a $2.5 \%$ wage cut depend on the macro model in which it is embedded, our reaction is neither to dismiss this effect as negligible nor to argue that it is likely to represent an overwhelming factor in the economy. At one extreme, assume a Keynesian monetarist-type model, in which a $2.5 \%$ reduction in wages reduces prices by $2.5 \%$. Supposing, further, that this is equivalent to a $2.5 \%$ expansion in output, then employment will increase $2.5 \%$ (given constant returns to scale). At another extreme, assume that a $2.5 \%$ reduction in wages does not affect prices at all (they are set on world markets) 
so that the reduction in wages raises employment along a demand curve. If the elasticity of demand is taken conservatively to be about one half, we would have 1\%: higher employment, giving us a range of employment effects from $1 \frac{1}{4}$ to $2 \frac{1}{2} \%$.

This kind of counterfactual historical exercise should be understood in proper perspective. First of all, the calculations are extremely crude. Secondly, they are based on a particular interpretation of a particular theory. Thirdly the "thought experiment" is necessarily artificial. (If there were lower bonuses but higher base wages, it could be argued, wages might become more flexible, timing in the economy might be altered, or fiscal or monetary policy might be changed, perhaps thereby neutralizing some of the effects calculated here.)

These limitations notwithstanding, we think the exercise is useful for gaining some rough insight into the likely size of what might be called the "pure bonus effect." We interpret the orders of magnitude involved as suggesting that the Japanese bonus system may have exerted a non-negligible macroeconomic influence by helping automatically to boost employment without inflationary pressure. But the significance of an "as if" $3 \%$ money wage cut is not nearly so great as to account for the entire unemployment story, nor to eliminate output fluctuations, 25 nor to do away with the need for discretionary policy to maintain full employment, especially in the face of severe economic shocks.

That the bonus system alone cannot possibly be explaining the entire macroeconomic adjustment story is made abundantly clear by the extreme example of Japan's response to the energy crisis. After the first oil shock, in 1974, consumer prices increased by about $25 \%$ and wholesale prices by over 30\%; output in manufacturing and mining fell by $10 \%$. At first the unions had no better premonition than anyone else that a permanent terms-of-trade deterioration was 
underway, and were concerned to recoup lost purchasing power as well as to obtain their customary pay increase. In the spring offensive of that year, base wages jumped by $33 \%$, strike days lost were 2.7 per 10,000 , a rate double that in previous years and above the rate in the U.S. in many years. An observer looking simply at these figures would have predicted that the Japanese economy would have been more likely to have gone into a major stagflation decline than the U.S. or European economies. But such was not the case. At this point, when the mechanics of a potentially vicious wage-price spiral started to become evident, the famous Japanese consensus took over. Government officials, labor experts, businessmen, and labor union leaders began preaching wage and price restraint. The 1975 shunto saw base wages increase by only 13\%, and they have been held to the single digit range since then; the consumer price index rate of increase fell to $10.4 \%$, and while output in manufacturing and mining declined by $4.4 \%$ in 1975 it rose by $10.8 \%$ in 1976 . Strike days lost fell sharply to 0.9 per 10,000 in 1976 and to virtually zero in succeeding years.26

Because base wages constitute three fourths of Japanese pay, and on ly part of bonuses are responsive to profits (revenue), the deceleration of wage increases was quantitatively more important in stabilizing employment than was the adjustment of bonuses. However much the Japanese bonus system may be helping as an automatic employment stabilizer (months of bonus pay declined sharply after 1974-- see the Appendix figures), in stepping back from high inflation in the mid-1970s Japan relied upon flexible wage-setting to a greater extent than flexible bonuses, as it had to, given the share of wages in total compensation and the magnitude of the macroeconomic shock.

\section{Conclusion}

In this paper we have examined a relatively unique aspect of the Japanese labor market -- payment of bonuses which constitute a quarter of workers' pay. 
Our analysis has rejected the notion that bonuses are just another form of wage payment on two grounds: (1) bonuses behave differently than wages over the cycle, responding to profits and responding more to revenues than do wages; and (2) bonuses affect employment differently from wages, having a positive rather than negative link to employment. While bonuses are not set by pure share economy principles, they are sufficiently responsive to profits or revenues and affect employment in ways that have the flavor of a share economy. Our estimate is that they contribute somewhat to the success of the Japanese economy by automatically helping to stabilize unemployment at relatively low levels. The importance of reductions in the rate of change of base wages during the first oil crisis, however, makes it clear that, as presently constituted, the bonus system in Japan is by no means the main factor behind Japanese ability to weather severe shocks of that kind better than most other developed countries. This example highlights our basic conclusion. The bonus system helps Japan to maintain relatively tight labor markets, but so too do other, probably complementary aspects of the Japanese system beyond the focus of this study. 


\section{Footnotes}

1. Weitzman, (1984), (1985).

2. Shimada (1983) contains an excellent survey of the English language literature.

3. Koike (1983a), (1983b), and references therein, sometimes argues the contrary view that Japanese industrial relations, and particuarly the lifetime employment system, are not nearly so unique as is sometimes made out. He has a point when he does not push this view too hard. Another view is contained in Hashimoto and Raisian (1985). Tachibanaki notes that much of the difference in job tenure in Japan and the U.S. results from workers obtaining permanent jobs directly out of school in Japan whereas in the U.S. workers job shop before taking a permanent job.

4. For discussion of the nenko system, see, e.g., Shimada (1983) or Shirai (1983b). Also see Tachibanaki (1982).

5. For descriptions of the Japanese workplace, see Koshiro (1983a). See also Koike "Skill Formation System in the U.S. and Japan: A Comparative Study" in Aoki(1984).

6. On many of these points see Shirai (1983b). Hours adjustments are discussed in Hamada and Kurosaka (1984).

7. In this calculation we divide bonuses by operating profits. Using a narrower measure of profits, "current profits," we get anywhere from 56-160 percent between 1965 and 1983 .

8. This interpretation is emphasized by, among others, Shirai (1983b), p. 131. 
9. See the Appendix table.

10. See, e.g., Okuno (1984).

11. See Grossman.

12. The Okuna data here calculated are from the union's report to its workers. The standard deviations for manufacturing are calculated from the Ministry of Labor data in our Appendix table.

13. Koshiro (1983b), pp. 241-242, contains a good discussion of bonus responsiveness to profits. For figures on firms with explicit profit-sharing see Japanese Ministry of Labor, General Survey on Wage and Working Hours System.

14. If there is any resultant error in bonuses, it would induce negative correlation with profits less bonuses.

15. We recognize that bonuses and wages are set separately but since we omitted a relevant variable in both equations, we get wages entering the bonus equation as a proxy for the omitted variable.

16. See, e.g., Grubb, Jackman, and Layard (1983), Koshiro (1983b), or the results reported in Hamada and Kurosaka (1985).

17. See the references in 17 .

18. One interpretation of the "better" results for manufacturing than for all industry is that we are not identifying a demand equation in a full employment economy.

19. The equation $\ln (E)=a+b \ln (B+W)+c \ln (B)+d \ln (N D P)+e T$ ime $+f \ln \left(E_{-1}\right)$ was estimated for 10 manufacturing industries with the following results: 
Number of industries with Number of industries with coefficients $b<0$ and $c>0$ other values for $b$ and/or $c$

Total

$|t|<1$

$1<|t|<2$

$2<t \mid<3$

$|t|>3$
6

1

2

3

0
4

3

1

0

0

The manufacturing industries included are: FO, TX, PA, CH, PE, FB, MA, EQ, TQ, PC. See Data Appendix for industry codes.

Similar results were obtained estimating

$$
\ln (E)=a+b \ln (B+w)+c \ln (W)+d \ln (N D P)+e T i m e+f \ln \left(E_{-1}\right)
$$

20. The equation $\ln (E)=a+b \ln (B+w)+c \ln (B)+d \ln (N D P)+e T i m e+f \ln \left(E_{-1}\right)$ was estimated for 6 non-manufacturing industries with the following results:

Number of industries with Number of industries with
coefficients $b<0$ and $c>0$ other values for $b$ and/or $c$

Total

$|t|<1$

2

2

$1<t \mid<2$

1

1

The non-manufacturing industries included are: MI, WR, FI, RE, TC, EL. See data appendix for industry codes.

Similar results were obtained estimating $\ln (E)=a+b \ln (B+W)+c \ln (W)+d \ln (N D P)+e T i m e+\ln \left(E_{-I}\right)$ 
21. In terms of the usual supply-demand graph bonuses are a measure of the gap between supply and demand along the cost axis at the point where employment is set in a share economy.

22. It should be noted that Japan's number one status in having the lowest unemployment rate among major industrialized economies did not emerge until the 1970 's. In the 1960 's, some other countries like Germany had equally good employment records. There has been some discussion in the literature about the extent to which Japanese statistics may underestimate the unemployment rate by international standards. Taira (1983) and a few others have tried to argue this case. But it is not very convincing (see, e.g., Sorrentino(1984), Hamada and Kurosaka(1985)). The basic point is that when reasonable adjustment measures are applied uniformly to all countries in an attempt to make international standards more uniform, then al1 countries' unemployment rates increase slightly, but without much altering their relative standing. Japan's unemployment record remains outstanding even after playing the readjustment game.

23. If the relevant contract adjustment period is more than a year, due to pay parameter stickiness, the profit-sharing component grows in importance relative to the base wage component because of the distributed-lag difference equation buildup. In that case the effect of profit-sharing is somewhat more pronounced. It is hard to imagine how imputed base wages as seen by the employer could decline much more than about $5 \%$ below total pay.

24. See Weitzman(1985). The basic idea is that the effect on the firm of converting $2 \frac{2}{2} \%$ of pay from base wages to profit shares is to lower wages by three percent while simultaneously being subjected to a compensating tax on profits. 
25. Depending on how output is detrended from its high growth rates, Japanese output stability might be judged outstanding or mediocre. Actually, Japan has the steadiest growth rate among all OECD countries over the past quarter century if it is measured by relative deviations from a standardized mean. In terms of absolute deviations from a non-standardized mean, Japanese growth shows much more cyclical variability. Note that, with a sprinkling of temporary price stickiness, the relevant model of a profit-sharing economy would predict relatively full employment but some building up of inventories, make-work, or labor hoarding during slack periods. Thus, the large Okun coefficient for Japan (see Hamada and Kurosaka (1984)) is not in itself a theoretical contradiction with shareeconomy-1ike interpretations.

26. Data in this paragraph are taken from Japan Productivity Center Practical Handbook of Productivity and Labor Statistics, 1985. 


\section{References}

Aoki, Masahiko, ed. (1984): The Economic Analysis of the Japanese Firm. Amsterdam: North Holland.

Grubb, David, Jackman, Richard, and Layard, Richard (1983): "Wage Rigidity and Unemployment in OECD Countries." European Economic Review, 21, pp. 11-39.

Grossman, Herschel, and Haraf, William F. "Shunto, Rational Expectations, and Output Growth in Japan" NBER Working Paper \#1144, June 1983.

Hamada, Koichi, and Kurosaka, Yoshio (1984): "The Relationship Between Production and Unemployment in Japan: Okun's Law in Comparative Perspective." European Economic Review 25, 1 (June), 71-94.

Hamada, Koicki, and Kurosaka, Yoshio (1985): "Trends in Unemployment, Wages, and Productivity: The Case of Japan," paper prepared for the Conference on the Rise in Unemployment, May 1985.

Hashimoto, M. and J. Raisian "Employment Tenure and Earnings Profile in Japan and the U.S." American Economic Review, September 1985, pp. 721-735.

Ishikawa, Tauneo, and Ueda, Kazuo (1984): "The Bonus Payment system and the Japanese Personal Savings" in M.Aoki, ed., The Economic Analys is of the Japanese Firm.

Koike, Kazuo (1983a): "Internal Labor Markets: Workers in Large Firms: in T. Shirai, ed., Contemporary Industrial Relations in Japan.

Koike, Kazuo (1983b): "Workers in Small Firms and Women in Industry" in T. Shirai, ed., Contemporary Industrial Relations in Japan.

Koshiro, Kazutoshi (1983a): "The Quality of Working Life in Japanese Factories" in T. Shirai, ed., Contemporary Industrial Relations in Japan.

Koshiro, Kazutoshi (1983b): "Development of Collective Bargaining in Postwar Japan" in T. Shirai, ed., Contemporary Industrial Relations in Japan.

Okuno, Masahiro (1984): "Corporate Loyalty and Bonus Payments", in M. Aoki, ed. , The Economic Analysis of the Japanese Firm.

Shimada, Haruo (1983): "Japanese Industrial Relations-- A New General Mode1? A Survey of the English-Language Literature" in T. Shirai, ed., Contemporary Industrial Relations in Japan.

Shirai, Tashiro, ed. (1983): Contemporary Industrial Relations in Japan. Madison: University of Wisconsin Press.

Shirai, Tashiro (1983b): "A Theory of Enterprise Unionism" in T. Shirai, ed., Contemporary Industrial Relations in Japan.

Sorrentino, Constance (1984): "Japan's Low Unemployment: an In-Depth Analysis." Monthly Labor Review 107, 3 (March), 18-27.

Symons, J. and R. Layard "Neoclassical Demand for Labor Functions" London School of Economics Discussion Paper 166. 
Tachibanaki, Toshiaki (1982): "Further Results on Japanese Wage Differentials: Nenko Wages, Hierarchical Position, Bonuses, and Working Hours" International Economic Review 23, No.2 (June).

Taira, Koji (1983): "Japan's Low Unemployment: Economic Miracle or Statistical Artifact?" Monthly Labor Review 106, 7 (July), 3-10.

Wadwani, Sushil (1985): "The Macroeconomic Implications of Profit Sharing: Some Empirical Evidence", working paper, L.S.E.

Weitzman, Martin L. (1984): The Share Economy. Cambridge: Harvard University Press.

Weitzman, Martin L. (1985): "The Simple Macroeconomics of Profit Sharing". American Economic Review (December). 
DATA APPENDIX

\section{Industry Code Definitions}

AL.......AIl Industries Covered

MI........Mining

CN..........Construction

WR.......Wholesale and Retail Trade

FI.........Finance and Insurance

RE.......Real Estate

TC........ Transportation and Communication

El.......Electricity, Gas and Water

MF........Manufacturing

FO....Food, Tobacco and Kindred Products

TX.... Textile Mill Products

AP....Apparel and Related Products

LU... . Lumber and Wood Products

RU....Furniture and Fixtures

PA....Pulp, Paper and Paper Products

PR....Publishing, Printing, and Allied Products

$\mathrm{CH}$..... Chemical and Allied Products

PE.... Petroleum and coal Products

RU.... Rubber and Rubber Products

LE.... Leather and Leather Products

IS..... Iron and Steel

NF.... Non-ferrous Metals and Products

FB.... Fabricated Metal Products

MA.... Machinery

EQ....Electrical Machinery, Equipment and Supplies

TQ.... Transportation Equipment

PC....Precision Machinery 


\section{Data Definitions and Sources}

\section{VARIABLE NAME}

$B^{\star} \quad$ Bonuses

E Emp loyees

1964-1983:

1958-1963:

\section{DEFINITION AND SOURCE}

Special cash payments not included in any previous contract, agreement or rule. Average yen per month per regular worker in firms with 5 or more regular workers. Monthly average over the calendar year. Japanese Ministry of Labor, Monthly Labor Statistics.

Total number of regular workers employed indefinitely or under contract for a period longer than one month, in establishments with a least 5 regular workers. Data for January 1st of each year were shifted to a calendar year average. Japanese Ministry of Labor, Yearbook of Labor Statistics, Survey on Employment Trend.

Non-manufacturing Industries.

The number of regular workers employed in establishments with at least 5 regular workers, by industry, was estimated with the following methodology:

$A=$ number of regular workers in firms with 30 or more regular workers, available for December 31st of each year. Japanese Ministry of Labor, Yearbook of Labor Statistics, Labor Turnover Survey.

$B=$ total number of employees in firms with 5 or more regular workers. This data was available for December 31 st of 1957, 1960 and 1963; data for other years were interpolated between these figures. Japanese Census of Establishments, Bureau of Labor Statistics, Office of the Prime Minister.

$C=$ total number of employees in firms with 30 or more regular workers. Availability and source same as for B.

This series was then calculated as $A \star(B / C)$.

The ratio $B / C$ is used as an estimate of the ratio of regular workers in firms with 5 or more regular workers to regular workers in firms with 30 or more (the actual ratio was unavailable except for 1960.) A comparison of the two ratios for 1960 by industry was favorable, indicating that the estimate is a fairly good one. The end of year data for 1958-63 was scaled to a first of year basis based on the 1963/1964 comparison. The first-of-year series was then shifted to a calendar year average.

Manufactur: Industries

The number of regular workers employed in establishments with at least 5 regular workers, by industry, was estimated with the following methodology:

$A=$ number of regular workers in firms with 30 or more regular workers, on December 31 st of each year. 
NoP* Net Domestic
Product

P** Profit

Time Time Trend

VA** Value Added

$W^{\star} \quad$ Wages

WPI Price Index
Japanese Ministry of Labor, Yearbook of Labor Statistics, Labor Turnover Survey.

$B=$ total number of employees in firms with between 4 and 29 regular workers, on December 31 st of each year. Japanese office of the Prime Minister, Japan Statistical Yearbook, Census of Manufacturing.

$C=$ ratio of total employees to regular workers in firms with 5 to 29 regular workers, for 1960. Japanese Census of Establishments, Bureau of Labor Statistics, Office of the Prime Minister.

This series was then calculated as $A+(B \times C)$. This end of year data for 1958-63 was scaled to a first of year basis based on the 1963/64 comparison. The entire series was then shifted to a calendar year average.

Net output by industrial origin at market prices over the calendar year. In 1978 the Japanese Economic Planning Agency overhauled its system of national accounts, resulting in some discrepancies in the time series. Because of this the 1970-79 (ARNA) series is spliced on to the 1979-83 (ARNA) series, and 1958-74 (ARNIS) is spliced on to 1970-83 (ARNA). Japanese Economic Planning Agency, Annual Report on National Accounts (ARNA), previously Annual Report on National Income statistics (ARNIS). This data was used on a fiscal year basis in tables 1 through 4 and on a calendar year basis in tables 5 and 6 .

Total corporate operating profit for firms of all sizes by industry for fiscal years. (e.g. data for 1960 covers April 1, 1959-March 31, 1960). Statistical Survey of Corporate Enterprise.

Linear time trend over all years in sample.

Total corporate value added for firms of all sizes by industry for fiscal years. (e.g. data for 1960 covers April 1, 1959- March 31, 1960.) Statistical Survey of Corporate Enterprise.

Cash earnings paid on the basis of previously determined contracts, collective agreements or wage regulations. Average yen paid per month per regular worker in firms with 5 or more regular workers. Monthly average over the calendar year. Japanese Ministry of Labor. Yearbook of Labor statistics.

Calendar year average of the wholesale price index by groups of commodities, 1980=100. Industries were assigned the price index of the most closely aligned commodity. Bank of Japan, Economic Statistics Annual.

*Variable deflated by the WFI.

* Variable deflated by a fiscel year wifl calculated as:

FYWFIt $=3 / 4 W F I_{-1}+1 / 4 W P I_{t}$ 
$1 v$

Appendix Table A

齿䓌

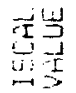

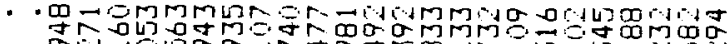

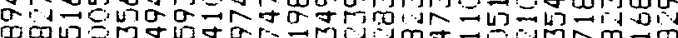
Mog

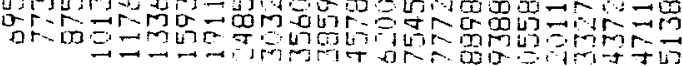

空

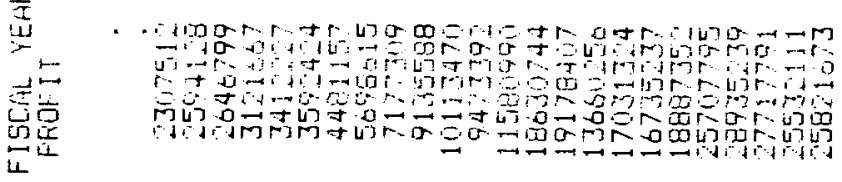

it a

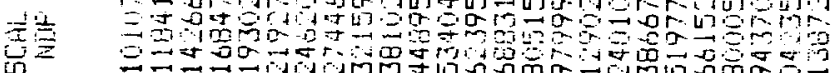

突

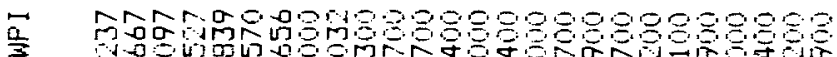

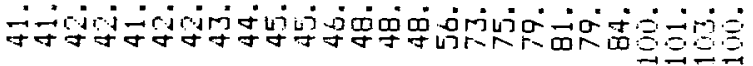

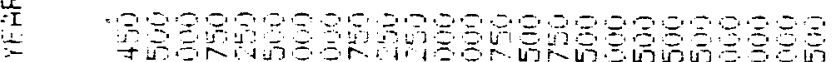

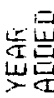

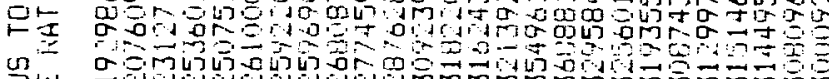
蓆

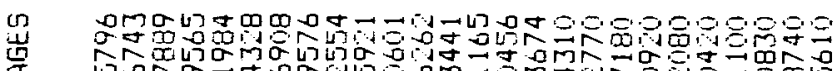

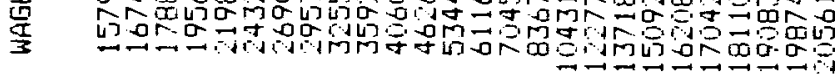

If 400100-0m0000000000000000

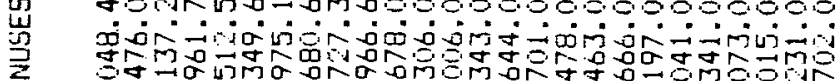

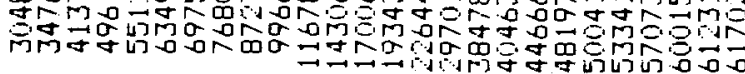

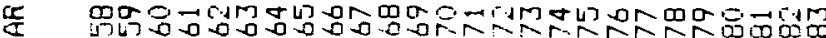
岁

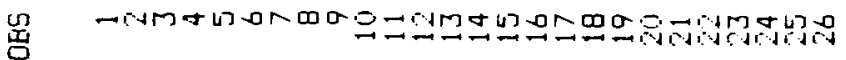

正岁

步

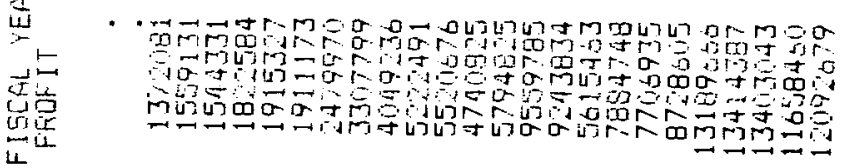

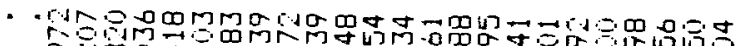

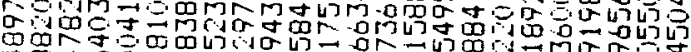

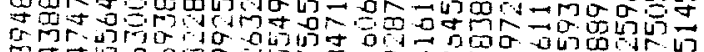

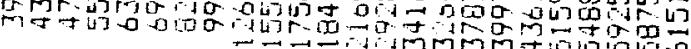

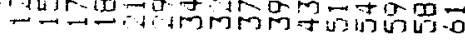

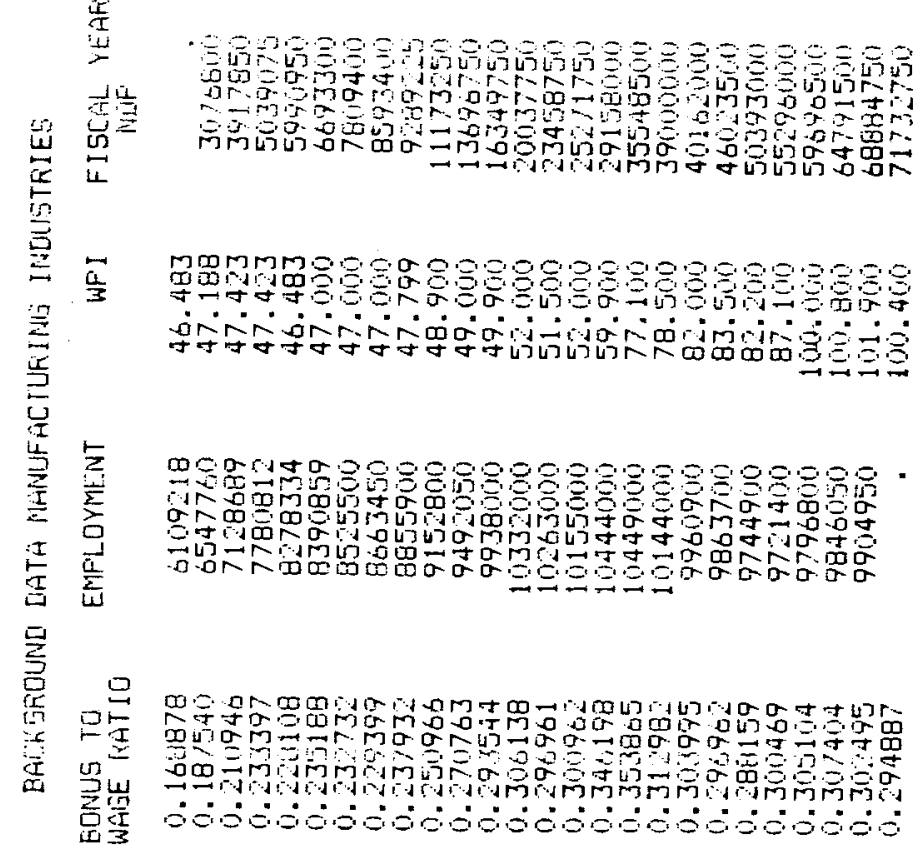

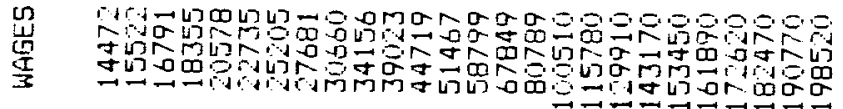

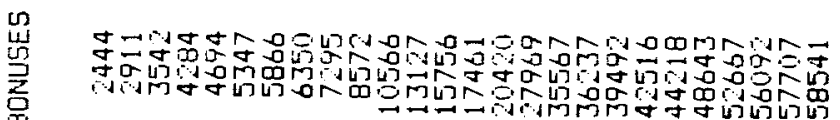

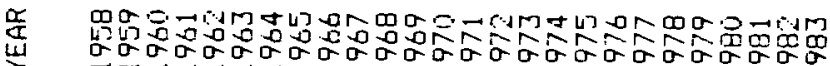

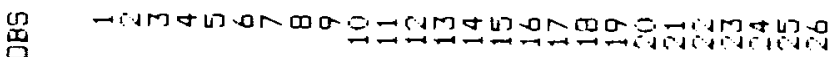

